\title{
部分乾留木炭内装ペレットにおける酸化鉄の還元挙動
}

\section{Reduction Behavior of Iron Oxide in Semi-chacoal Composite Pellets}

\author{
小西宏 和*・藤 森士 朗**・碓 井建 $*^{*}$ \\ Hirokazu KONISHI, Shiro FUJIMORI and Tateo USUI
}

(Received October 22, 2008)

\begin{abstract}
Biomass has a novel advantage, i.e., no $\mathrm{CO}_{2}$ emissions, because of carbon neutral. We proposed semi-charcoal composite iron oxide pellets in order to decrease reducing agent at blast furnace and $\mathrm{CO}_{2}$ emissions. Japanese cedar were carbonized partly at maximum carbonization temperatures $\left(\mathrm{T}_{\mathrm{C}, \max }=823,1073\right.$ and $\left.1273 \mathrm{~K}\right)$ in order to obtain semi-charcoal with residual volatile matter (V.M.). It was found that the semi-charcoal retained much V.M., mainly $\mathrm{H}_{2}$, at $\mathrm{T}_{\mathrm{C} \text {, } \max }=823 \mathrm{~K}$ and that the semi-charcoal with some residual V.M. could be prepared by controlling $\mathrm{T}_{\mathrm{C}, \max }$ in the carbonization. Composite pellets using such semi-charcoal have been prepared and reduced at reduction temperature $\left(\mathrm{T}_{\mathrm{R}}\right)$ in $\mathrm{N}_{2}$ gas atmosphere. Fractional reductions $F(\%)$ of the semi-charcoal composite pellets at $\mathrm{T}_{\mathrm{C}, \max }=823,1073$ and $1273 \mathrm{~K}$ were $17 \sim 24 \%$ for $60 \mathrm{~min}$ at $\mathrm{T}_{\mathrm{R}}=1073 \mathrm{~K}$. Moreover, fractional reduction $F(\%)$ of the semi-charcoal composite pellet at $\mathrm{T}_{\mathrm{C}, \max }=823 \mathrm{~K}$ was $62 \%$ for 60 min at $\mathrm{T}_{\mathrm{R}}=1173 \mathrm{~K}$ and was higher than the pellet at $\mathrm{T}_{\mathrm{C} \text {, max }}=1273 \mathrm{~K}$ by about $30 \%$. When $\mathrm{T}_{\mathrm{C} \text {, max }}$ was lower, namely the pellet had more residual V.M., the reduction of iron oxide was more accelerated at $\mathrm{T}_{\mathrm{R}}=1073$ and $1173 \mathrm{~K}$. Fractional reductions $F(\%)$ of all the semi-charcoal composite pellets were about 100 $\%$ for $50 \sim 60 \mathrm{~min}$ at $\mathrm{T}_{\mathrm{R}}=1273 \mathrm{~K}$. These reducibility of semi-charcoal composite pellets were higher than those of semi-coal-char composite pellets at $T_{R}=1273 \mathrm{~K}$.
\end{abstract}

Key Words: Biomass, Ironmaking, Volatile Matter, Semi-charcoal, Reduction of Iron Oxide

\section{1. 緒 言}

我が国では地球温暖化への対応として、2005 年 2 月に発 効した京都議定書に示されるように 2008 年度から 2012 年 度までの 5 年間 1990 年比 $6 \%$ の温室効果ガス排出削減を 目標としているが、2004 年度の温室効果ガス総排出量は 13 億 2900 万トンであり、1990 年に比べて $7.4 \%$ も増加して いる ${ }^{1)}$ 。このような状況の中、鉄鋼業はすでに自主行動計画 によって $10.5 \%$ の $\mathrm{CO}_{2}$ 排出量の削減を目指して様々な技 術開発を進めているが、粗鋼生産量の増大も相まって、目 標達成には至っていない2)。一方、石炭、石油、天然ガスな どの化石燃料を代替する資源としてバイオマスが注目を集 めている。バイオマスとは「エネルギーや素材として利用 されうる再生可能な生物由来の有機性資源」、すなわちカー ボンニュートラルであるため、その使用に際して排出され る $\mathrm{CO}_{2}$ は大気中の $\mathrm{CO}_{2}$ 濃度を増加させないという利点を有 している。また、バイオマス資源の量は膨大であり、その 年間生成量の $10 \%$ のエネルギーが利用可能だとしても、そ の量は世界の年間一次エネルギー消費量にほぼ匹敵する3)。
とりわけ、我が国では未利用の木質系バイオマスが年間約 4270 万トンも発生しており、その有効利用が課題とされて いる ${ }^{4)}$

また、我が国の鉄鋼業を取り巻く環境の変化として、 2002 年以降、世界の粗鋼生産量は中国をはじめとする生産 拠点の拡大により、2004 年 10 億トン台に、2005 年には 11 億トンを記録、さらに 2006 年度末には 13 億トンを超える 情勢にある。この急速な増大に連動して鉄鉱石の世界的な 需給環境も大きく変化し、鉱山会社の合併と寡占化、良質 なへマタイト鉱の枯渇、高結晶水鉱石の増加など鉱石資源 の安定確保が厳しくなってきている。石炭資源においても 高品位炭の需給は逼迫しており、こうした原料事情の悪化 の中で鉱石や強粘結炭の価格はこれまでにない上昇に直面 している5 。このような問題を解決するため、鉄鋼業では新 たな高炉装入物として粘結性が低い劣質炭でも使用できる 炭材内装塊成鉱の開発に取り組み始めている。炭材内装塊 成鉱は鉄鉱石、石炭、ダスト、スラッジ等をペレットやブ リケット状に塊成化したもので、従来コールドボンド法で 製造され回転炉床炉を中心に使用されてきたが、近年高炉

*大阪大学 大学院工学研究科 マテリアル生産科学専攻（～565-0871 大阪府吹田市山田丘 2-1）

Division of Materials and Manufacturing Science, Graduate School of Engineering, Osaka University (2-1 Yamadaoka, Suita, Osaka 565-0871 Japan) **大阪大学 工学部学生 現 日新製鋼(侏)

Undergraduate Student, School of Engineering, Osaka University, now NISSHIN STEEL CO., LTD. 
Table 1 Analyses of Japanese cedar and Newcastle blend coal used in this study (mass\%).

\begin{tabular}{|c|c|c|c||c|c|c|c|c|}
\hline & F.C. & V.M. & Ash & S & C & H & O & N \\
\hline Japanese cedar & 12.05 & 87.38 & 0.57 & 0.01 & 52.52 & 6.76 & 40.4 & 0.03 \\
\hline Newcastle blend coal & 53.4 & 41.3 & 5.3 & 0.55 & 74.7 & 1.49 & 12.9 & 5.13 \\
\hline
\end{tabular}

Table 2 Chemical analysis of Bentonite used in this study (mass\%).

\begin{tabular}{|r|l|l|l|l|l|l|}
\hline $\mathrm{SiO}_{2}$ & $\mathrm{Al}_{2} \mathrm{O}_{3}$ & $\mathrm{Fe}_{2} \mathrm{O}_{3}$ & $\mathrm{CaO}$ & $\mathrm{MgO}$ & $\mathrm{K}_{2} \mathrm{O}$ & $\mathrm{Na}_{2} \mathrm{O}$ \\
\hline 58.79 & 14.27 & 2.99 & 0.70 & 1.28 & 0.70 & 3.42 \\
\hline
\end{tabular}

をはじめとする一部の堅型炉でも使用され始めている。高 炉での使用量は少量であるが、使用上の問題点として、結 晶水や付着水の影響によるシャフト上部での昇温・還元遅 れ、セメントなどのバインダーに由来するスラグ比の増加 や冷間強度不足による炉頂排出ダストの増加などが指摘さ れている6。さらに、製造面の課題として、輸送や装入等に 必要な強度を得るための養成に長い時間と広大な用地を要 する点が挙げられる。

炭材内装塊成鉱の還元挙動に関しては還元反応機構の解 明、還元速度および金属化率の向上を目的とした基礎的な 研究が精力的に実施され、その還元反応は塊成鉱内の伝導 伝熱律速であり、還元速度の向上には石炭と鉱石の接触面 積の増加、すなわち塊成鉱の密度向上が有効であるという ことが報告されている7)。また、その還元反応機構は外部 からの還元ガスの拡散によって支配される通常のペレット や焼結鉱とは異なり、高温加熱によって内部で生成された $\mathrm{CO}$ ガスが還元とガス改質を繰り返しながら粒子内で連鎖 反応的に還元に寄与するため、ペレット内部での炭材のガ ス化反応 (カーボン・ソリューション・ロス反応 ) に大き く依存するという報告もされている ${ }^{8)}$ 。さらに、炭材内装塊 成鉱の還元反応は炭材と酸化鉄の固体 - 固体間反応が起点 となるため、低温から反応を開始させるためには、炭材と 酸化鉄を微粉砕・混合すること采、石炭と鉄鉱石を熱間成形

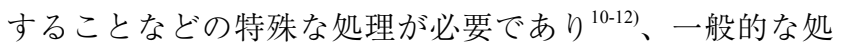
理方法では非常に難しいことがわかっている。

本研究では、高炉内における熱保存帯温度低下と還元材 比低減、さらには製鉄プロセスにおける $\mathrm{CO}_{2}$ 排出量の削 減を計るため、部分乾留チャー内装塊成鉱の開発を進めて いる。ここで、部分乾留チャーとは、石炭の昇温乾留時 に乾留最高温度 $\mathrm{T}_{\mathrm{C}, \text { max }}$ を制御することによって、チャーに 揮発分を一部残留させたものである。このような部分乾留 チャー内装ペレット中の残留揮発分は、昇温過程で $\mathrm{T}_{\mathrm{C}, \text { max }}$ 付近から徐々に発生し始め、酸化鉄の還元反応ならびに連 鎖的に内装炭材のガス化反応に大きく寄与することが期待 される。この効果により、従来の炭材内装塊成鉱よりもよ り低温からの気体 - 固体反応の開始を起点として、気相を
介して固体 - 固体反応をも促進する可能性がある。これま でに、部分乾留したチャーと酸化鉄を混合して炭材内装酸 化鉄ペレットを作製し、その還元挙動を検討してきた ${ }^{13)} 。$ 本報では、木質系バイオマスを炭材として用いた新規「部 分乾留木炭内装塊成鉱」の開発を目的とした。具体的には、 乾留最高温度 $\mathrm{T}_{\mathrm{C}, \max }=823 、 1073 、 1273 \mathrm{~K}$ で部分乾留した 木炭を酸化鉄と混合して部分乾留木炭内装ペレットを作製 し、 $\mathrm{N}_{2}$ ガス䨌囲気下で等温還元実験を行い、その還元挙動 を検討した。

\section{2. 実験方法}

\section{1 試料}

木質系バイオマスの試料として市販のスギ木材を、酸化 鉄試料として $\mathrm{Fe}_{2} \mathrm{O}_{3}$ 試薬 $(95.0 \%$ ：和光純薬工業(株)）を用 いた。スギ木材の分析值と、比較試料としてニューキャッ スルブレンド炭の分析值を Table 1 に示す。スギ木材の方 が水素、酸素量が多く、硫黄、窒素量が少ない。木材乾留 実験の後、得られた木炭は $64 \mu \mathrm{m}$ 以下に粒径を揃えた。整 粒した木炭と $\mathrm{Fe}_{2} \mathrm{O}_{3}$ 試薬を、炭材中の固定炭素モル量と被 還元酸化鉄中の酸素モル量が等しくなるように、質量比約 $1: 4$ の割合で、遊星型ボールミル（ステンレス鋼製）を 用いて $30 \mathrm{~min}$ 混合した。ペレット強度を保持するため、 バインダーとしてベントナイト（和光純薬工業(株）を 1.0 mass\% 添加し、イオン交換水を加えてハンドローリング法 によって直径約 $15 \mathrm{~mm}$ 、質量約 $2 \mathrm{~g}$ の木炭内装ペレットを 作製した。ベントナイトの組成を Table 2 に示す。その組 成より酸化鉄の還元反応にはほとんど影響しないと考えら れる。その後、表面付着水を除去するためにペレットをオー ブンで $378 \mathrm{~K} 、 24 \mathrm{~h}$ 以上保持した。

\section{2 木材乾留実験}

木炭内装ペレットに用いる部分乾留木炭を得るため、木 材乾留実験を行った。木材乾留装置を Fig. 1 に示す。木材 充填層は、プログラム温度制御式のシリコニット電気炉を 用いて加熱した。ここで、各ガス流量の定量（いわゆる内 部標準法）のため、一定流量 $1.67 \times 10^{-5} \mathrm{~m}^{3} / \mathrm{s}$ (s.t.p.) の $\mathrm{N}_{2}$ ガ 


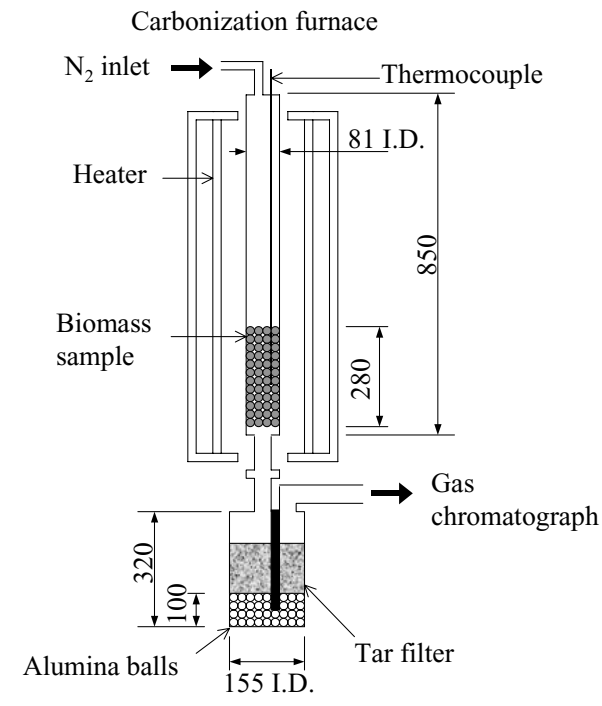

Fig. 1 Schematic draw of experimental apparatus for carbonization; dimensions in $\mathrm{mm}$.

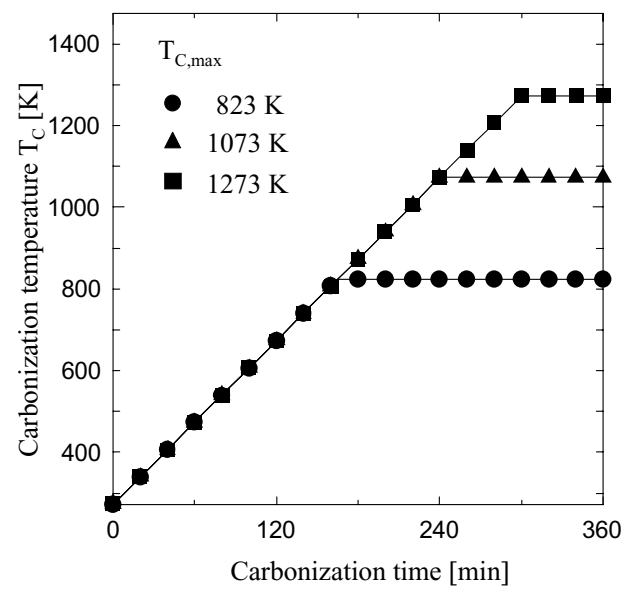

Fig. 2 Changes of carbonization temperature with time.

スを乾留ガスに付加した ${ }^{14)}$ 。 $\mathrm{N}_{2}$ ガスは Fig. 1 の乾留反応管 上部のパイプから流入し、乾留反応管内部の木材充填部を 通過し、ここで揮発分と混合した後、タールフィルター（グ ラスウール）によりタールを除去した。得られたガス成分 については $20 \mathrm{~min}$ 毎にガスクロマトグラフ (侏)島津製作所： GC14B）によって分析した。乾留実験に用いた木材は 200 gである。木材乾留の昇温パターンを Fig. 2 に示す。室温 から乾留最高温度 $\mathrm{T}_{\mathrm{C}, \max }=823 、 1073 、 1273 \mathrm{~K}$ まで $200 \mathrm{~K} / \mathrm{h}$ で昇温し、 $\mathrm{T}_{\mathrm{C}, \text { max }}$ 到達後、乾留時間 $\mathrm{t}=360 \mathrm{~min}$ まで $\mathrm{T}_{\mathrm{C}, \text { max }}$ で 保持した。その後、同一流量の $\mathrm{N}_{2}$ ガス流通下で放冷した。

\section{3 木炭内装酸化鉄ペレットの等温還元実験}

作製した試料をアルミナ坩堝に入れ、 $\mathrm{N}_{2}$ ガス䨌囲気下で 還元温度 $T_{R}=1073 、 1173 、 1273 \mathrm{~K}$ に昇温した炉内に瞬時に

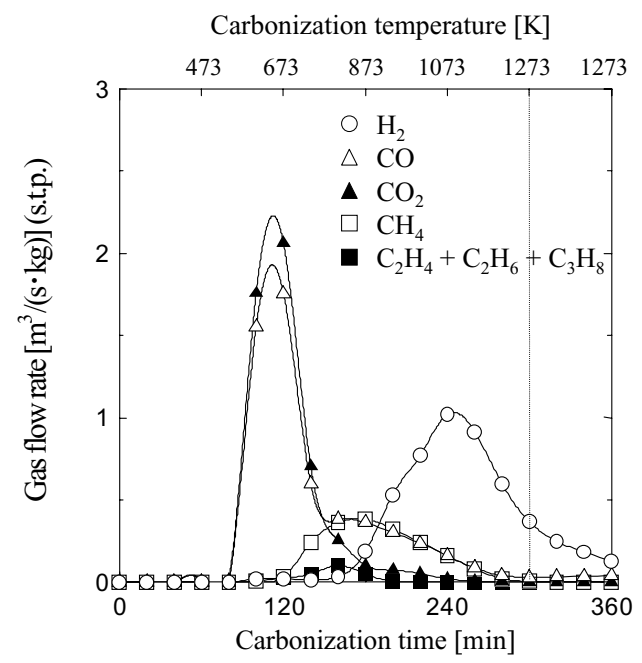

Fig. 3 Variations of gas flow rate with carbonization time using Japanese cedar at $T_{C, \max }=1273 \mathrm{~K}$.

設置し、等温還元実験を行った。生成ガスはガスバッグで 捕集し、ガスクロマトグラフによりガス組成を求め、還元 率 $F$ を算出した。還元時間は $60 \mathrm{~min} 、$ 生成ガスのサンプリ ング間隔と $\mathrm{N}_{2}$ ガスの流量は $\mathrm{T}_{\mathrm{R}}=1073 、 1173 \mathrm{~K}$ で $10 \mathrm{~min} 、 1.67$ $\times 10^{-6} \mathrm{~m}^{3} / \mathrm{s}$ (s.t.p.)、 $\mathrm{T}_{\mathrm{R}}=1273 \mathrm{~K}$ で $5 \mathrm{~min} 、 3.33 \times 10^{-6} \mathrm{~m}^{3} / \mathrm{s}$ (s.t.p.) とした。

\section{3. 結果と考察}

\section{1 木材乾留ガスの発生挙動}

$\mathrm{T}_{\mathrm{C}, \max }=1273 \mathrm{~K}$ で乾留した際のスギ木材 $1 \mathrm{~kg}$ 当たりの生 成ガス流量の経時変化を Fig. 3 に示す。約 $500 \mathrm{~K}$ から CO、 $\mathrm{CO}_{2}$ が生成し始め、673 $\mathrm{K}$ 付近でその生成量は最大となる。 その後、 $\mathrm{CO}_{2}$ は $873 \mathrm{~K}$ 以上でほとんど生成しなくなる。一方、 $\mathrm{CO}$ は $873 \mathrm{~K}$ 付近から生成量がなだらかに減少する。 $\mathrm{CH}_{4}$ および高次の炭化水素系ガスは $673 \mathrm{~K}$ 付近から生成し始め、 約 $773 \sim 873 \mathrm{~K}$ で生成量が最大となった後、減少した。 $\mathrm{H}_{2}$ は $873 \mathrm{~K}$ から生成し始め、生成量は $1073 \mathrm{~K}$ 付近で最大とな り、その後、なだらかに減少していった。すべてのガスに

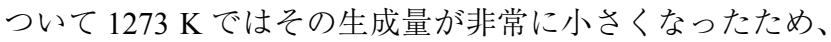
$\mathrm{T}_{\mathrm{C}, \max }=1273 \mathrm{~K}$ の木炭の残留揮発分は少ないことが示唆さ れる。

$\mathrm{T}_{\mathrm{C}, \max }=1073 \mathrm{~K}$ で乾留した際のスギ木材 $1 \mathrm{~kg}$ 当たりの生 成ガス流量の経時変化を Fig. 4 に示す。 $\mathrm{T}_{\mathrm{C}, \max }=1273 \mathrm{~K}$ 乾 留の際と同様な傾向を示している。しかし、 $\mathrm{H}_{2}$ の生成ピー ク付近 $1073 \mathrm{~K}$ で昇温を止めたため、それ以降の $\mathrm{H}_{2}$ 生成量 は急激に減少する。ここで得られた $\mathrm{T}_{\mathrm{C}, \max }=1073 \mathrm{~K}$ の木炭 には、 $\mathrm{CO} 、 \mathrm{CH}_{4} 、 \mathrm{H}_{2}$ などの還元性ガスが揮発分として $\mathrm{T}_{\mathrm{C}}$, ${ }_{\max }=1273 \mathrm{~K}$ の木炭よりも多量に残存していることが示唆さ れる。

$\mathrm{T}_{\mathrm{C}, \max }=823 \mathrm{~K}$ で乾留した際のスギ木材 $1 \mathrm{~kg}$ 当たりの生 
成ガス流量の経時変化を Fig. 5 に示す。 $823 \mathrm{~K} て ゙$ 昇温を止 めたため、 $\mathrm{H}_{2}$ はわずかしか生成しなかった。ここで得られ た $\mathrm{T}_{\mathrm{C}, \max }=823 \mathrm{~K}$ の木炭には、 $\mathrm{T}_{\mathrm{C}, \max }=1073 、 1273 \mathrm{~K}$ の木炭 よりもさらに多量の揮発分が残存していることが示唆され る。

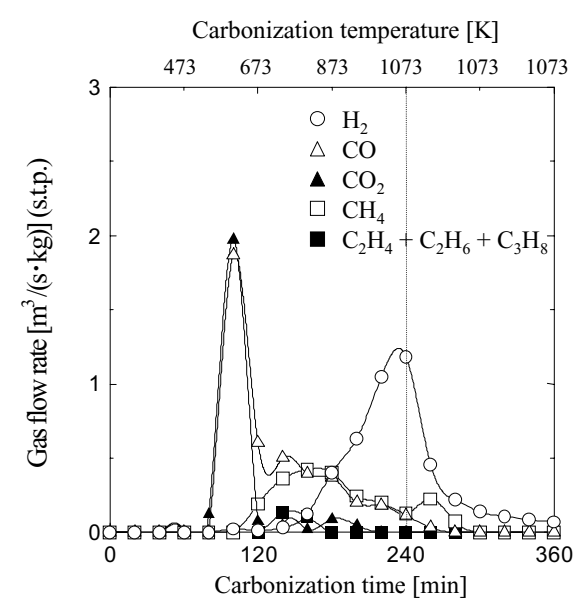

Fig. 4 Variations of gas flow rate with carbonization time using Japanese cedar at $T_{C, \text { max }}=1073 \mathrm{~K}$.

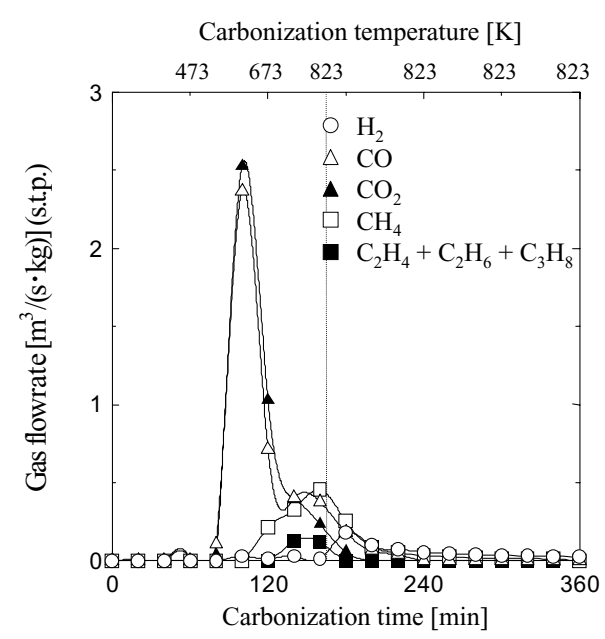

Fig. 5 Variations of gas flow rate with carbonization time using Japanese cedar at $\mathrm{T}_{\mathrm{C}, \max }=823 \mathrm{~K}$.

\section{2 乾留ガス組成分析および石炭との比較}

得られた部分乾留木炭および比較試料である部分乾留石 炭チャーの工業分析值および化学分析值を Table 3 に示す。 $\mathrm{T}_{\mathrm{C}, \max }=823 \mathrm{~K}$ の木炭の揮発分は $22 \%$ と、 $\mathrm{T}_{\mathrm{C}, \max }=1073 \mathrm{~K}$ よ りも $12 \%$ 以上高かった。石炭チャーも同様に、 $\mathrm{T}_{\mathrm{C}, \max }=823$ $\mathrm{K}$ の揮発分が、 $\mathrm{T}_{\mathrm{C}, \max }=1073 \mathrm{~K}$ よりも $11 \%$ 以上高かった。 木炭と石炭チャーの揮発分をそれぞれの $\mathrm{T}_{\mathrm{C}, \max }$ で比較する と木炭の方が $5 \sim 6 \%$ 程度高かった。残留揮発分量の結果 を踏まえると、木炭の方が還元に有利であることが示唆さ れる。

さらに、スギ木材の乾留により生成したガス成分の総体 積を Fig. 6 に示す。比較データとして石炭乾留時に得られ た值 ${ }^{13)}$ も示す。スギ木材乾留では $\mathrm{T}_{\mathrm{C}, \max }$ が低いほど生成ガ スの量は少ない。ここで $\mathrm{H}_{2}$ 以外のガス成分の生成量の変 化は小さかったが、 $\mathrm{H}_{2}$ は $\mathrm{T}_{\mathrm{C}, \max }$ の低下とともに大きく減少 した。このことから $\mathrm{T}_{\mathrm{C}, \max }=823 \mathrm{~K}$ の木炭には多量の $\mathrm{H}_{2}$ が 残存していることが示唆される。一方、石炭とスギ木材を $\mathrm{T}_{\mathrm{C}, \max }=1273 \mathrm{~K}$ で比較すると、石炭では $\mathrm{CH}_{4}$ および高次の 炭化水素系ガス、 $\mathrm{H}_{2}$ が 2 倍以上生成した。このことから石 炭は揮発分として $\mathrm{H}$ をスギ木材よりも多く含有しているの で、酸化鉄の還元に対する $\mathrm{H}$ の寄与は木炭より大きいこと

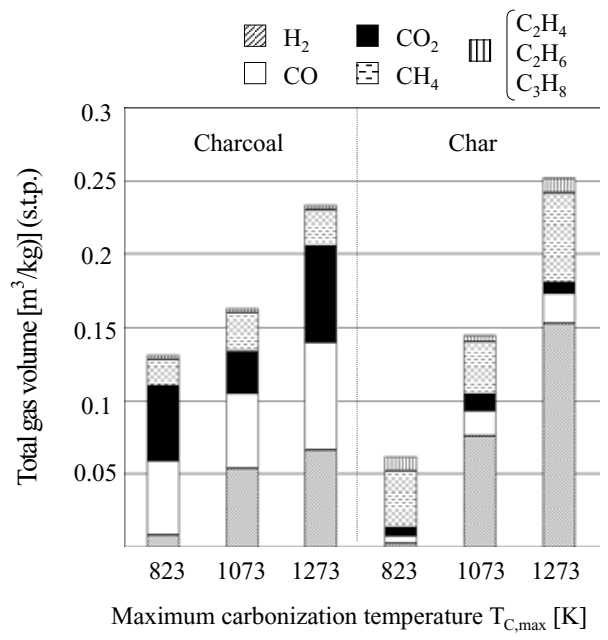

Fig. 6 Total gas volumes generated by carbonization of charcoal and coal as a function of maximum carbonization temperature $T_{C \text {, max }}$.

Table 3 Analyses of charcoal and char obtained by carbonization of Japanese cedar and Newcastle blend coal.

\begin{tabular}{|c|c|c|c|c||c|c|c|c|c|}
\hline & Component & F.C. & V.M. & Ash & C & H & O & N & S \\
\hline \multirow{4}{*}{ Charcoal } & $\mathrm{T}_{\mathrm{C}, \max }=823 \mathrm{~K}$ & 76.02 & 22.09 & 1.29 & 84.23 & 2.52 & 11.95 & - & 0.01 \\
\cline { 2 - 10 } & $\mathrm{T}_{\mathrm{C}, \max }=1073 \mathrm{k}$ & 88.62 & 9.45 & 1.93 & 91.90 & 0.91 & 5.20 & - & 0.06 \\
\cline { 2 - 10 } & $\mathrm{T}_{\mathrm{C}, \max }=1273 \mathrm{~K}$ & 90.13 & 7.66 & 2.21 & 92.16 & 0.92 & 3.91 & 0.69 & 0.11 \\
\hline \hline \multirow{4}{*}{ Char } & $\mathrm{T}_{\mathrm{C}, \max }=823 \mathrm{~K}$ & 72.17 & 15.93 & 11.9 & 75.33 & 2.87 & 7.31 & 2.06 & - \\
\cline { 2 - 10 } & $\mathrm{T}_{\mathrm{C}, \max }=1073 \mathrm{k}$ & 82.7 & 4.43 & 12.87 & 81.52 & 1.54 & 1.91 & 1.74 & - \\
\cline { 2 - 10 } & $\mathrm{T}_{\mathrm{C}, \max }=1273 \mathrm{~K}$ & 83.21 & 2.51 & 14.28 & 81.69 & 0.9 & 1.34 & 1.27 & - \\
\hline
\end{tabular}




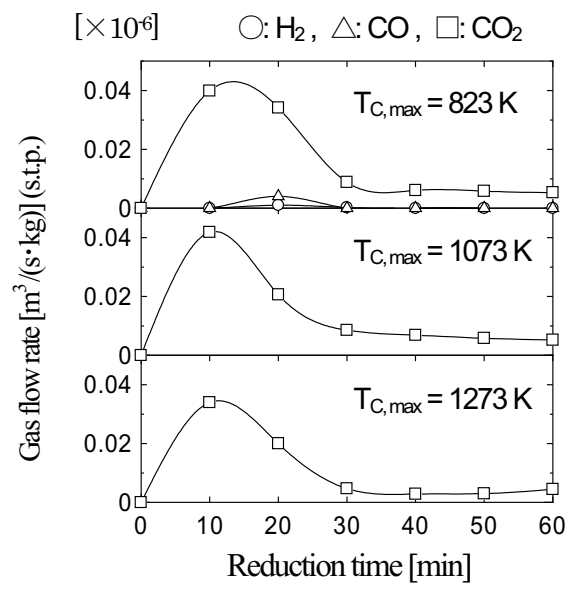

Fig. 7 Variations of gas flow rate of carbon composite pellets using semicharcoal during reduction at $T_{R}=1073 \mathrm{~K}$ in $\mathrm{N}_{2}$ gas atmosphere.

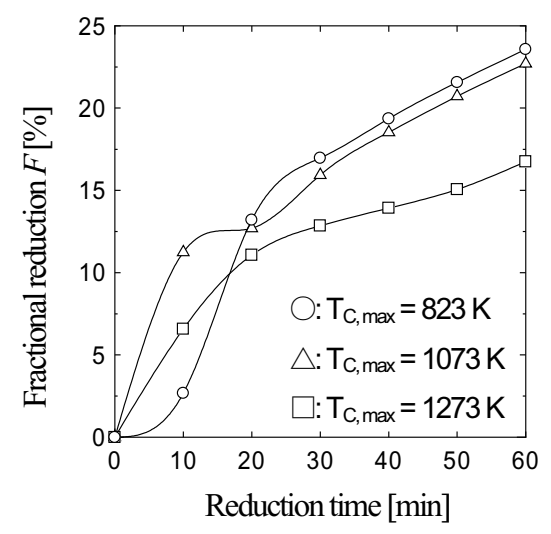

Fig. 8 Reduction curves of carbon composite pellets using semicharcoal at $T_{C, \max }=823,1073,1273 \mathrm{~K}$ at $\mathrm{T}_{\mathrm{R}}=1073 \mathrm{~K}$ in $\mathrm{N}_{2}$ gas atmosphere.

が示唆される。

\section{3 木炭内装ペレットの還元挙動の検討}

\subsection{1 $\mathrm{T}_{\mathrm{R}}=1073 \mathrm{~K}$ における等温還元実験}

部分乾留木炭内装ペレットを $\mathrm{T}_{\mathrm{R}}=1073 \mathrm{~K}$ で等温還元し た際の生成ガス流量の経時変化を Fig. 7 に示す。酸化鉄の 還元により多量の $\mathrm{CO}_{2}$ が生成していることがわかる。また、 その生成量は $\mathrm{T}_{\mathrm{C}, \max }$ が低いほど多くなった。一方 $\mathrm{T}_{\mathrm{C}, \max }=$ $823 \mathrm{~K}$ では $\mathrm{H}_{2} 、 \mathrm{CO}$ が発生していたが、 $\mathrm{T}_{\mathrm{C}, \max }=1073 、 1273$ $\mathrm{K}$ では生成しなかった。ここで、部分乾留木炭内装ペレッ トの還元におけるガス流量から還元率を計算した。得られ た還元曲線を Fig. 8 に示す。還元初期 10 min では $\mathrm{T}_{\mathrm{C}, \text { max }}=$ $1073 \mathrm{~K}$ の還元率が高い值を示した。一方、 $\mathrm{T}_{\mathrm{C}, \max }=1273 \mathrm{~K}$ の試料では $20 \mathrm{~min}$ まで還元率は急激に高くなるが、それ以 降は緩やかに上昇した。6 $60 \mathrm{~min}$ 経過時点の還元率は 17 $24 \%$ で、 $\mathrm{T}_{\mathrm{C}, \max }$ の低いものほど高かった。これらの結果から、 $\mathrm{T}_{\mathrm{R}}=1073 \mathrm{~K}$ 等温還元では $60 \mathrm{~min}$ 以降に揮発分による酸化

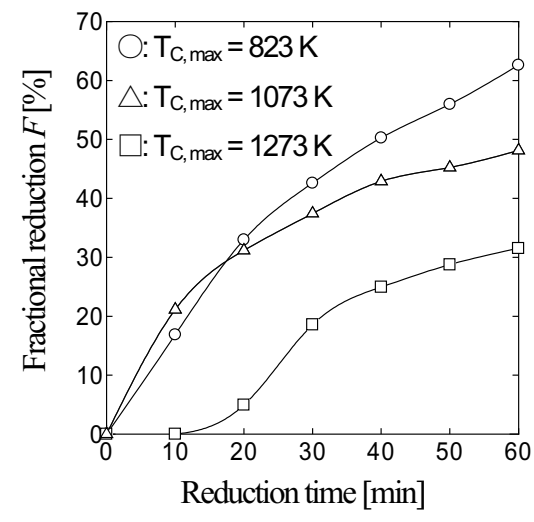

Fig. 9 Variations of gas flow rate of carbon composite pellets using semicharcoal during reduction at $T_{R}=1173 \mathrm{~K}$ in $\mathrm{N}_{2}$ gas atmosphere.

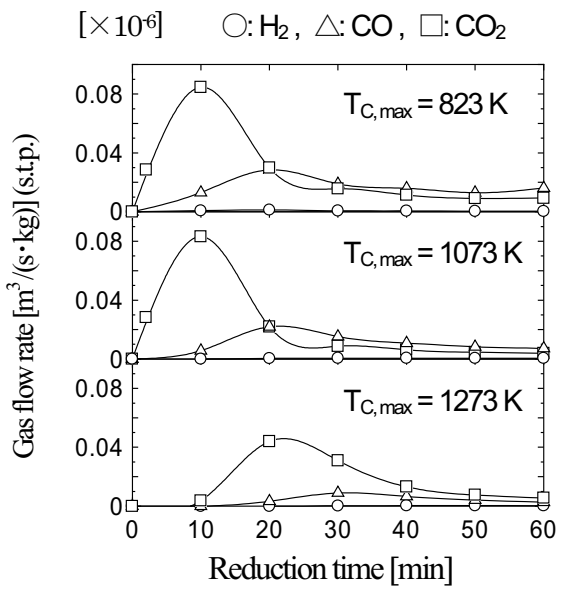

Fig. 10 Reduction curves of carbon composite pellets using semicharcoal at $T_{C, \max }=823,1073,1273 \mathrm{~K}$ at $T_{R}=1173 \mathrm{~K}_{\text {in }} \mathrm{N}_{2}$ gas atmosphere.

鉄の還元効果が確認されたが、還元初期 10 min においては 揮発分による還元効果が確認できなかった。

3.3.2 $\mathrm{T}_{\mathrm{R}}=1173 \mathrm{~K}$ における等温還元実験

部分乾留木炭内装ペレットを $\mathrm{T}_{\mathrm{R}}=1173 \mathrm{~K}$ で等温還元し た際の生成ガス流量の経時変化を Fig. 9 に示す。生成ガス は主に $\mathrm{CO}_{2}$ であったが、 $\mathrm{T}_{\mathrm{R}}=1073 \mathrm{~K}$ 還元のときより $\mathrm{CO}$ 生 成量が増加した。 $40 \mathrm{~min}$ 以降では $\mathrm{H}_{2} 、 \mathrm{CO} 、 \mathrm{CO}_{2}$ の生成量 が一定の割合で平衡した。ここで生成した $\mathrm{H}_{2}$ は木炭中の 水分とカーボンとのソリューションロス反応により生成し た可能性がある。 $\mathrm{T}_{\mathrm{R}}=1173 \mathrm{~K}$ における還元曲線を Fig. 10 に示す。 $60 \mathrm{~min}$ 経過時点での還元率は $30 \sim 62 \%$ で、 $\mathrm{T}_{\mathrm{C} \text {, max }}$ が $823 \mathrm{~K}>1073 \mathrm{~K}>1273 \mathrm{~K}$ の順で還元率が高いことがわ かった。ここでも $\mathrm{T}_{\mathrm{C}, \max }$ が低いほど、すなわち揮発分量が 多い試料ほど $20 \mathrm{~min}$ 以降において揮発分の還元反応に対す る効果が現れた。また $\mathrm{T}_{\mathrm{C}, \max }=823 \mathrm{~K}$ と $1273 \mathrm{~K}$ の還元率の 差は $60 \mathrm{~min}$ で約 $30 \%$ であり、揮発分の還元反応に対する 


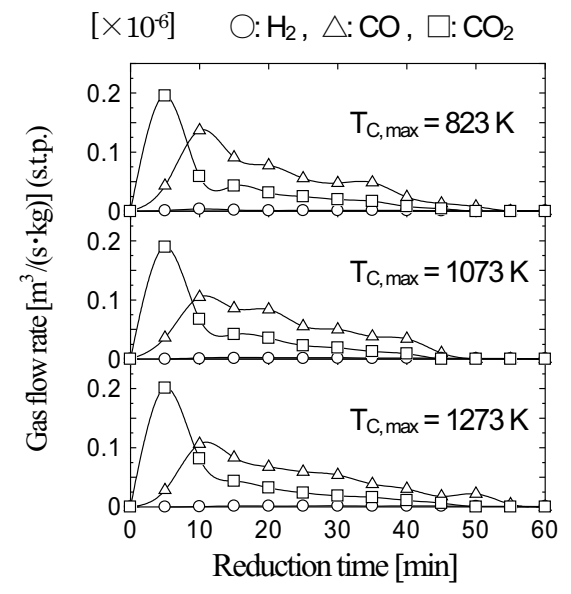

Fig. 11 Variations of gas flow rate of carbon composite pellets using semi-charcoal during reduction at $T_{R}=1273 \mathrm{~K}$ in $\mathrm{N}_{2}$ gas atmosphere.

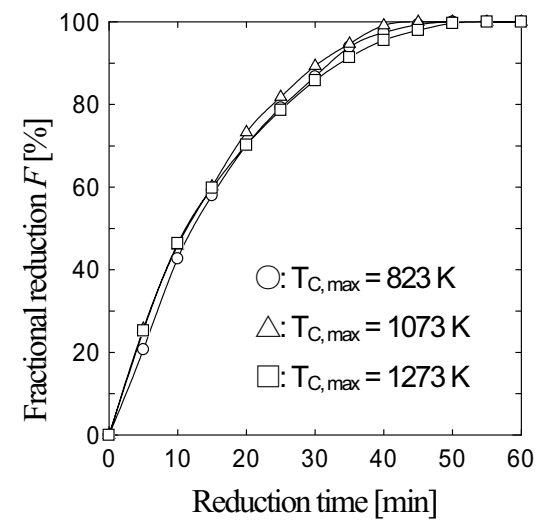

Fig. 12 Reduction curves of carbon composite pellets using semicharcoal at $\mathrm{T}_{\mathrm{C}, \max }=823,1073,1273 \mathrm{~K}$ with time at $\mathrm{T}_{\mathrm{R}}=1273$ $\mathrm{K}$ in $\mathrm{N}_{2}$ gas atmosphere.

効果は、 $\mathrm{T}_{\mathrm{R}}=1073 \mathrm{~K} よ り も 1173 \mathrm{~K}$ の等温還元において顕 著な差が生じた。これらの結果を踏まえると、 $\mathrm{T}_{\mathrm{R}}=1173 \mathrm{~K}$ では揮発分中の $\mathrm{H}_{2}$ が $\mathrm{FeO}$ から金属 $\mathrm{Fe}$ への還元反応、さら には炭材のガス化反応を促進させた可能性がある。

\subsection{3 $\mathrm{T}_{\mathrm{R}}=1273 \mathrm{~K}$ における等温還元実験}

部分乾留木炭内装ペレットを $\mathrm{T}_{\mathrm{R}}=1273 \mathrm{~K}$ で等温還元し た際の生成ガス流量の経時変化を Fig. 11 に示す。生成ガ スはすべての試料で同じような経時変化を示した。各ガス 成分は $\mathrm{T}_{\mathrm{C}, \max }=823 \mathrm{~K}$ では $55 \mathrm{~min} 、 \mathrm{~T}_{\mathrm{C}, \max }=1073 \mathrm{~K}$ では 50 $\min 、 \mathrm{~T}_{\mathrm{C}, \max }=1273 \mathrm{~K}$ では $60 \mathrm{~min}$ で生成しなくなり、還元反 応が終了したことがわかった。

$\mathrm{T}_{\mathrm{R}}=1273 \mathrm{~K}$ における還元曲線を Fig. 12 に示す。この温 度では還元反応は非常に速く進み、 $\mathrm{T}_{\mathrm{C}, \max }$ すなおち揮発分 による還元率の差はほとんど生じなかった。このことから 高温域では還元反応に対する揮発分の効果が小さいことが 示された。

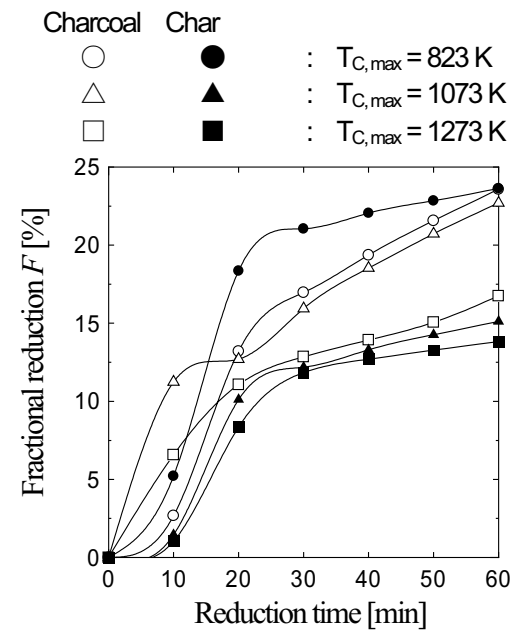

Fig. 13 Reduction curves of carbon composite pellets using semicharcoal and semi-coal-char at $\mathrm{T}_{\mathrm{C}, \max }=823,1073,1273 \mathrm{~K}$ at $\mathrm{T}_{\mathrm{R}}$ $=1073 \mathrm{~K}$ in $\mathrm{N}_{2}$ gas atmosphere.

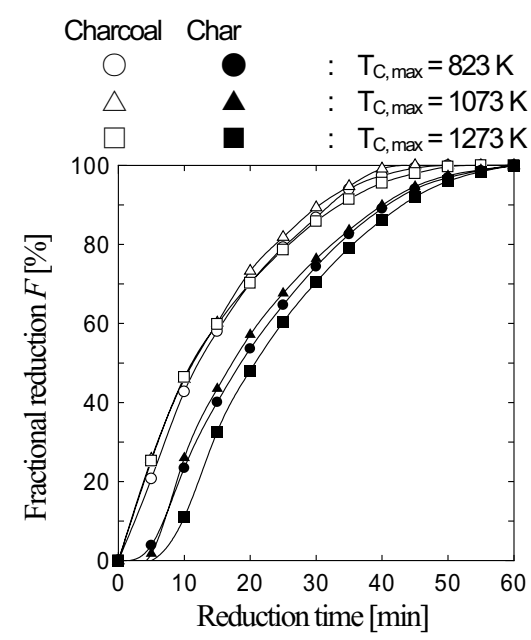

Fig. 14 Reduction curves of carbon composite pellets using semicharcoal and semi-coal-char at $\mathrm{T}_{\mathrm{C}, \max }=823,1073,1273 \mathrm{~K}$ at $\mathrm{T}_{\mathrm{R}}$ $=1273 \mathrm{~K}$ in $\mathrm{N}_{2}$ gas atmosphere.

\section{4 炭材種による還元性の比較}

$\mathrm{T}_{\mathrm{R}}=1073 \mathrm{~K}$ における木炭内装ペレットと比較データ ${ }^{15)}$ と して石炭チャー内装ペレットの還元曲線を Fig. 13 に示す。 石炭チャー内装ペレットでは揮発分量の差による還元率の 違いが明らかとなっている。木炭内装ペレットは 3 条件と も $\mathrm{T}_{\mathrm{C}, \max }=823 \mathrm{~K}$ の石炭チャー内装ペレットより還元率が 低いことがわかった。これらの結果から、石炭チャーの方 が水素を多く含有しているため、酸化鉄の還元がより速く 進行したことが示唆された。さらに、 $\mathrm{T}_{\mathrm{R}}=1273 \mathrm{~K}$ 還元にお ける木炭内装ペレットと石炭チャー内装ペレットの還元曲 線を Fig. 14 に示す。ここでは木炭内装ペレットの還元が 非常に速く進行しており、全ての試料において木炭内装ぺ レットの方が還元率が高い值を示した。これらの結果から、 
$\mathrm{T}_{\mathrm{R}}=1273 \mathrm{~K}$ の高温域では、残留揮発分量に関係なく、非晶 質な構造を持つ木炭の方が結晶性の良い石炭よりも還元性 が高いことがわかった。

\section{4. 結論}

乾留最高温度 $\mathrm{T}_{\mathrm{C}, \text { max }}=823 、 1073 、 1273 \mathrm{~K}$ で部分乾留した 木炭（スギ）を用いて、部分乾留木炭内装酸化鉄ペレット を作製し、その還元挙動を検討した結果、以下の結論を得 た。

(1) $\mathrm{T}_{\mathrm{C}, \max }=823 \mathrm{~K}$ で乾留することで、 $\mathrm{T}_{\mathrm{C}, \max }=1073 \mathrm{~K}$ で乾留 した木炭よりも、 $12 \%$ 以上多くの揮発分が残留した。 また、残留揮発分は主に $\mathrm{H}_{2}$ であった。乾留ガス成分の 総体積において、スギ木材は石炭と比べて $\mathrm{H}_{2}$ の割合は 小さいことがわかった。

(2) $1073 \mathrm{~K}$ 等温還元では $60 \mathrm{~min}$ 経過時点の還元率は 17 $24 \%$ で、 $\mathrm{T}_{\mathrm{C}, \max }$ の低いものほど高かった。

(3) $1173 \mathrm{~K}$ 等温還元でも $T_{\mathrm{C}, \text { max }}$ の低いものほど還元率は高 く、 $\mathrm{T}_{\mathrm{C}, \text { max }}=823 \mathrm{~K}$ と $1273 \mathrm{~K}$ の還元率の差は $60 \mathrm{~min}$ で約 $30 \%$ であった。

(4) $1273 \mathrm{~K}$ 等温還元ではすべての $\mathrm{T}_{\mathrm{C}, \max }$ の試料で、 $50 \sim 60$ min で還元反応が終了した。どの試料の還元率もほぼ同 じ值を示し、還元に対する揮発分の効果は小さかった。

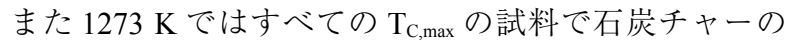
試料よりも高い還元率を示した。

\section{引用文献}

1) 環境省ホームページ (2005).

2）有山達郎、佐藤道貴、石井純: 一貫製鉄所に扔ける $\mathrm{CO}_{2}$ 削減の
課題と今後の展望、 $\mathrm{CO}_{2}$ 削減シンポジウム $\mathrm{CO}_{2}$ 削減に向けて の鉄鋼技術の進展、社日本鉄鋼協会 高温プロセ又部会、(平成 18 年 1 月)、23-24.

3) 文部科学省科学技術政策研究所 科学技術動向研究センター 編 著: 水素エネルギー最前線、工業調査会、2003, 160.

4) 井熊均 編著: 眓解よくわかるバイオエネルギー、日刊工業新 聞社、2004, 42 .

5) M. Shimizu and M. Naito: Tetsu-to-Hagané, 92 (2006), 694-702.

6) A. Kasai, M. Naito, Y. Matsui and Y. Yamagata: Tetsu-to-Hagané, 89 (2003), 1212-1219.

7) A. Kasai, Y. Matsui, F. Noma, H. Iwakiri and M. Shimizu: Tetsu-toHagané, 87 (2001), 313-319.

8) 小野陽一、井口義章、碓井建夫、高橋礼二郎、葛西栄輝、山 口一良、内藤誠章、清水正賢、川口尊三、上城親司 : 酸化鉄 の炭素還元の基礎と応用、(社)日本鉄鋼協会 高温プロセス部会 還元反応研究グループ、(平成 12 年 3 月)、 19.

9) J. Vahdati Khaki, Y. Kashiwaya, K. Ishii and H. Suzuki: ISIJ Int., 42 (2002), 13-22.

10) Y. Ueki, T. Maeda, M. Shimizu, Y. Matsui and A. Kasai: Tetsu-toHagané, 89 (2003), 1205-1211.

11) A. Kasai, M. Naito, Y. Matsui and Y. Yamagata: Tetsu-to-Hagané, 89 (2003), 1212-1219.

12) Y. Matsui, M. Sawayama, A. Kasai, Y. Yamagata and F. Noma: ISIJ Int., 43 (2003), 1904-1912.

13) H. Konishi, T. Usui and K. Azuma: Tetsu-to-Hagané, 92 (2006), $802-808$.

14) T. Usui, N. Inoue, T. Watanabe, T. Yokoyama, T. Oyama and Z. Morita: Ironmaking and Steelmaking, 31 (2004), 479-484.

15) H. Konishi, A. Yamashita and T. Usui: Journal of JSEM, 8 (2008), 142-146. 